\section{OPEN ACCESS}

Edited by:

László Hunyady,

Semme/weis University, Hungary

Reviewed by:

John Chang,

University of Alberta, Canada

Yves Combarnous,

Centre National de la Recherche

Scientifique (CNRS), France

*Correspondence: Stanko S. Stojilkovic stojilks@mail.nih.gov

Specialty section:

This article was submitted to Cellular Endocrinology, a section of the journal Frontiers in Endocrinology

Received: 04 February 2019 Accepted: 29 March 2019 Published: 17 April 2019

Citation:

Bjelobaba I, Janjic MM, Prévide RM, Abebe D, Kucka M and Stojilkovic SS (2019) Distinct Expression Patterns of Osteopontin and Dentin Matrix Protein

1 Genes in Pituitary Gonadotrophs.

Front. Endocrinol. 10:248.

doi: 10.3389/fendo.2019.00248

\title{
Distinct Expression Patterns of Osteopontin and Dentin Matrix Protein 1 Genes in Pituitary Gonadotrophs
}

\begin{abstract}
Ivana Bjelobaba ${ }^{1,2}$, Marija M. Janjic ${ }^{1,2}$, Rafael Maso Prévide ${ }^{1}$, Daniel Abebe ${ }^{1}$, Marek Kucka ${ }^{1}$ and Stanko S. Stojilkovic ${ }^{1 *}$

${ }^{1}$ Eunice Kennedy Shriver National Institute of Child Health and Human Development, National Institutes of Health (NIH), Bethesda, MD, United States, ${ }^{2}$ Institute for Biological Research Sinisa Stankovic, University of Belgrade, Belgrade, Serbia
\end{abstract}

Cell-matrix interactions play important roles in pituitary development, physiology, and pathogenesis. In other tissues, a family of non-collagenous proteins, termed SIBLINGs, are known to contribute to cell-matrix interactions. Anterior pituitary gland expresses two SIBLING genes, Dmp1 (dentin matrix protein-1) and Spp1 (secreted phosphoprotein-1) encoding DMP1 and osteopontin proteins, respectively, but their expression pattern and roles in pituitary functions have not been clarified. Here we provide novel evidence supporting the conclusion that Spp1/osteopontin, like Dmp1/DMP1, are expressed in gonadotrophs in a sex- and age-specific manner. Other anterior pituitary cell types do not express these genes. In contrast to Dmp1, Spp1 expression is higher in males; in females, the expression reaches the peak during the diestrus phase of estrous cycle. In further contrast to Dmp1 and marker genes for gonadotrophs, the expression of Spp1 is not regulated by gonadotropin-releasing hormone in vivo and in vitro. However, Spp1 expression increases progressively after pituitary cell dispersion in both female and male cultures. We may speculate that gonadotrophs signal to other pituitary cell types about changes in the structure of pituitary cell-matrix network by osteopontin, a function consistent with the role of this secretory protein in postnatal tissue remodeling, extracellular matrix reorganization after injury, and tumorigenesis.

Keywords: pituitary, gonadotrophs, SIBLINGs, Spp1, osteopontin, Dmp1, GnRH, cell-matrix

\section{INTRODUCTION}

Cell-extracellular matrix (ECM) tridimensional network is critical for the proper functioning of all tissues (1), including anterior pituitary gland (2). Individual components of ECM include two main classes of macromolecules; proteoglycans and fibrous proteins (laminin, collagens, elastins, and fibronectin) $(3,4)$. The effects of the ECM are mediated mainly by plasma membrane receptors called integrins; individual components of ECM bind to different integrins, leading to activation of multiple signaling pathways (5). In anterior pituitary, the presence of ECM molecules, like collagens, laminin, and small leucine-rich proteoglycans, and cell types producing these proteins have been identified (6-10). Pituitary cells also express integrins (11). There is increasing evidence that ECM is critical for development and differentiation of the pituitary gland (12), for postnatal cell migration and pituitary remodeling $(13)$, and for hormone secretion $(14,15)$. As in other tissues, ECM molecules may also have important roles in pituitary tumorigenesis (16). 
In addition to proteoglycans and fibrous proteins, ECM contains other proteins, including SIBLINGs (Small IntegrinBinding Ligand, N-linked Glycophosphoproteins). SIBLINGs are encoded by a family of five genes, comprising secreted phosphoprotein 1 (Spp1), which encodes osteopontin (OPN), integrin-binding sialoprotein, which encodes bone sialoprotein, and dentin matrix protein 1 ( Dmp1), dentin sialophosphoprotein and matrix extracellular phosphoglycoprotein, which encode proteins with the same name (17). SIBLINGs are soluble, secreted proteins that can act as modulators of cell adhesion as well as autocrine and paracrine ligands for ECM receptors. For example, OPN activates a variety of integrin receptors as well as CD44 receptor splice variants (18). The ligand activities of SIBLINGs are modulated by post-translational modifications, such as phosphorylation, glycosylation, proteolytic processing, sulphation, and transglutaminase cross-linking $(19,20)$.

SIBLINGs were initially described as mineralized tissueassociated genes (21). However, recent findings indicate that they are more widely distributed, including normal ductal epithelia in salivary gland (22) and kidney (23). Spp1/OPN were also detected in central nervous system (24), where they may play a role in neurodegenerative diseases, such as Alzheimer's disease (25), Parkinson's disease (26), and multiple sclerosis $(27,28)$. Dmp1/DMP1 was reported to be expressed in the brain, as well as in the liver, muscle, pancreas and kidney (29). SIBLING gene family is also expressed in various tumors $(18,30)$ and OPN was suggested to be a valuable biomarker for diagnosing and treating cancers (31).

Our recent RNA-sequence analysis revealed that $D m p 1$ and Spp1, but no other SIBLING genes, were also expressed in anterior pituitary cells (32). The expression of $D m p 1$ is restricted to gonadotrophs, cells that produce luteinizing hormone (LH) and follicle-stimulating hormone (FSH), and is stimulated by gonadotropin-releasing hormone $(\mathrm{GnRH})$ but not by other hypothalamic releasing factors. GnRH-induced expression of this gene is coupled with release of DMP1 in extracellular medium through the regulated secretory pathway. In vivo, the sex-specific pituitary Dmp1 expression is established during the peripubertal period and is elevated after ovulation. GnRH induction of Dmpl is mediated by the protein kinase C signaling pathway through ERK1/2 signaling pathway; in addition, the response is facilitated by progesterone (32). It has also been shown that Spp1 is expressed in gonadotrophs and that mRNA levels were down regulated in anterior pituitary of lactating animals and by injection of estradiol (33).

Here we summarize work on $S p p 1$ expression in rat anterior pituitary cells in vivo and in vitro. These include sexual dimorphism in Spp1 expression during maturation, effects of cell-matrix network destruction by cell dispersion procedure on Spp1 expression, and evaluation of the role of $\mathrm{GnRH}$ receptors (GnRHR) in the expression of this gene. We also studied the

\footnotetext{
Abbreviations: DMP1, dentin matrix protein 1; ECM, extracellular matrix; $\mathrm{FSH}$, follicle-stimulating hormone; GnRH, gonadotropin-releasing hormone; GnRHR, GnRH receptor; LH, luteinizing hormone; OPN, osteopontin; SIBLINGs, small integrin-binding ligand, N-linked glycophosphoproteins; Spp1, secreted phosphoprotein 1.
}

expression pattern of OPN in prepubertal females and males and cycling females as well as the cell type specificity in expression of this protein. Finally, we compared Spp1 expression with Dmp1 expression in pituitary gonadotrophs.

\section{METHODS}

\section{Animals}

Experiments were performed with female and male Sprague Dawley rats obtained from Taconic Farms (Germantown, NY). Animals were housed under constant conditions of temperature and humidity, with light on between 6 a.m. and 8 p.m. All experiments were repeated at least three times and were approved by the NICHD Animal Care and Use Committee (16-041).

\section{Ontogeny of Spp1/OPN Expression}

Experiments were performed with 2 days to 12 weeks old female and male rats. In some postpubertal females, a vaginal smear was taken of adult females to obtain information about the estrous cycle stage. Vaginal material was stained by a $0.1 \%$ aqueous solution of methylene blue and examined under a microscope. Animals were euthanized via asphyxiation with $\mathrm{CO}_{2}$ and whole pituitary or anterior pituitary glands were removed and used for histological preparations or RNA extraction as described below.

\section{Anterior Pituitary Cell Culture}

For in vitro experiments, 4- or 7-week-old female and male rats were euthanized in the morning. After decapitation anterior pituitary glands were removed and pituitary cells were mechanically dispersed after trypsin and EDTA treatments as previously described (34). Dispersed cells were seeded on polyD-lysine coated 24-well plates, 1.5 million per well. Plated cells were initially cultured in medium 199 containing Earle's salts, sodium bicarbonate, penicillin (100 units per $\mathrm{ml}$ ), streptomycin (100 $\mu \mathrm{g}$ per $\mathrm{ml}$ ) and 10\% heat-inactivated horse serum (Life Technologies, Grand Island, NY). If not otherwise specified, experiments were performed with cells cultured overnight, washed and bathed in medium 199 with Hank's salt and containing $0.1 \%$ BSA. At the end of experiments, attached cells were scraped for RNA extraction.

\section{In Vivo Treatments}

Four- or seven-week-old female and male rats were injected once intraperitoneally with a GnRHR agonist, buserelin acetate ( $5 \mu \mathrm{g} / 0.4 \mathrm{ml} /$ per animal) from Sigma (St. Louis, MO) or PBS $(0.4 \mathrm{ml} /$ per animal). Euthanasia was performed 3, 6, or $9 \mathrm{~h}$ after intraperitoneal injections. After decapitation, blood was collected, and serum was separated and stored at $-80^{\circ} \mathrm{C}$ for $\mathrm{LH}$ concentration measurement. The whole anterior pituitaries were collected in RNA later stabilization solution (Thermo Fisher Scientific, Waltham, MA) for RNA extraction.

\section{qRT-PCR Analysis}

Total RNA was extracted from individual anterior pituitary glands and primary cultures of anterior pituitary cells using RNeasy Plus Mini Kit (Qiagen, Valencia, CA). RNA was reverse transcribed with a Transcriptor First Stand cDNA 
Synthesis Kit (Roche Applied Sciences, Indianapolis, IN). Quantitative RT-PCR was performed using Applied Biosystems pre-designed Taq-Man Gene Expression Assays for rats using the LightCycler ${ }^{\circledR}$ TaqMan ${ }^{\circledR}$ Master Mix and the LightCycler 2.0 Real-time PCR system (Roche Applied Science). Target gene expression levels were determined by the comparative $2^{\wedge}$ (-delta $\mathrm{C}(\mathrm{T})$ ) quantification method using Gapdh as the reference gene, which was previously established to be a suitable reference gene for the anterior pituitary tissue (35). Applied Biosystems predesigned TaqMan Gene Expression Assays were used: Dmp1: Rn01450122_m1, Spp1 (Rn00681031_m1), Gnrhr (Rn00578981_m1), and Gapdh: Rn01462662_g1.

\section{Immunohistochemical Analysis}

Whole pituitaries were quickly and carefully isolated and fixed in Bouin's solution for $48 \mathrm{~h}$. Tissue was then embedded in paraffin and cut in coronal plane. Five $\mu \mathrm{m}$ thick sections were mounted on glass slides and processed for immunohistochemistry as previously described $(36,37)$. Briefly, after deparaffinization, antigen retrieval in citrate buffer $(0.01 \mathrm{M}, \mathrm{pH} 6)$ was performed. Monoclonal OPN antibody (The Developmental Studies Hybridoma Bank, Iowa City, IA) in 1:400 dilution was applied overnight at $4^{\circ} \mathrm{C}$. Secondary donkey anti-mouse-HRP (Santa Cruz Biotechnology, Dallas, TX) was then applied at 1:200 dilution for $2 \mathrm{~h}$, and visualization was afterwards performed with diaminobenzidine tetrahydrochloride (Vector Laboratories, Burlingame, CA). Slides were mounted with DPX (Sigma, St. Louis, MO) and sections examined under an Olympus BX61 microscope. For double immunofluorescence studies, after incubation of sections with the OPN antibody, secondary Alexa Fluor donkey-anti-mouse 488 (Thermo Fisher Scientific, Waltham, MA) was applied at 1:400 dilution for $2 \mathrm{~h}$. Sections were then incubated for $2 \mathrm{~h}$ with rabbit-anti rat $\mathrm{LH}$ or guinea pig-anti FSH (1:500 dilution) obtained from Dr. A. F. Parlow (National Institute of Diabetes and Digestive and Kidney Diseases, National Hormone and Peptide Program, Torrance, CA). Following the incubation with donkey-anti rabbit or donkey-anti guinea pig 555 Alexa Fluor secondary antibodies (1:400 dilution) slides were mounted with Mowiol based mounting medium and examined under inverted Zeiss LSM 510 confocal microscope. Triple immunofluorescence labeling was done as described above using Alexa Fluor Dyes: donkey-anti rabbit 488, donkey-anti guinea pig 555, and donkey-anti mouse 647 (Thermo Fisher Scientific, Waltham, MA), and the sections were examined under Leica TCS SP5 II confocal microscope.

\section{Statistics}

All numerical values in the text are reported as the mean \pm SEM from one of at least three similar in vivo or in vitro experiments. KaleidaGraph Program (Synergy Software, Reading, Pennsylvania) was used for all calculation and graph presentation. Significant differences between means were determined by a Student's $t$-test or an ANOVA accompanied with the post hoc Student-Newman-Keuls test as well as for regression/correlation analyses and calculation of the half time of decay in gene expression. $P$-values of $<0.05$ were considered significant.

\section{RESULTS}

\section{Spp1 Is Expressed in Anterior Pituitary of Developing Animals in a Sex-Specific Manner}

The Spp1 expression was investigated in male and female anterior pituitary tissue from 2 days to 12 weeks old rats (Figure 1A). During this period, the gene was expressed in both sexes and the mRNA expression varied between 5 and $70 \%$ of the expression of Gapdh, a housekeeping gene. Pituitaries obtained from animals up to 3 weeks of age showed no sex difference in the expression of Spp1. From week four onward, however, the sex-specific expression pattern was established. First, Spp1 levels were always significantly higher in male pituitaries. Second, there were differences in terms of timing needed to reach the peak in mRNA expression. In males, there was a progressive increase in Spp1 expression, reaching the peak value at 5 weeks of age, with $\sim 13$-fold increase in expression when compared to the second day of age. This was followed by a progressive decrease in gene expression during peripubertal and postpubertal periods. In females, however, the first peak in expression was reached during infantile period, with an $\sim 3$-fold increase compared to the second day of age. This was followed by a gradual decline during the juvenile, peripubertal and postpubertal age, with a secondary transient increase in expression at the age of 8 weeks (Figure 1A).

In both female and male rats, the developmental profiles of Spp1 were highly comparable to profiles of major gonadotrophspecific (hereafter marker) genes, Gnrhr, Lhb, and Fshb, as well as to the gonadotroph/thyrotroph-specific gene Cga (35). This prompted us to examine the relationship between Spp1 expression vs. marker gene expression during sexual maturation. This was done using a linear correlation analysis and the Pearson $r$-coefficient as an indicator of significance of correlation. Scatter data points for Gnrhr vs. Spp1 in developing males (Figure 1B) and females (Figure 1C), had a linear tendency, with the $r$ value significant in both cases.

Furthermore, Spp1 expression correlated well with the expression of $L h b, F s h b$, and Cga in males (Figures 2A-C). There was also correlation between $S p p 1$ vs. $C g a$ in females (Figure 2F), with comparable $r$-coefficient values in females and males, as well as between $S p p 1$ and $L h b$ expression (Figure 2D), but with lower $r$-coefficient in females when compared with males. Finally, the $r$-coefficient value was not significant when Spp1 expression was compared with Fshb expression in females (Figure 2E). The data points from prepubertal females (shown in gray) and in postpubertal females (shown in white) suggest that correlation was attenuated in postpubertal animals.

To clarify how the estrous cycle influences gene expression, we examined $L h b, F s h b, C g a$, and Spp1 expression in pituitaries from proestrus, estrus, and combined diestrus-1 (metestrus) and diestrus-2 animals. The expression of Lhb, Fshb, and Cga was highest in diestrus animals and lowest in estrus animals (Figure 2G). The pattern of Spp1 expression during of estrous cycle was different: the smallest was during proestrus $(2.84 \pm$ $0.70, n=14)$, followed by estrus $(7.50 \pm 0.89, n=8 ; P<0.01$ 
A

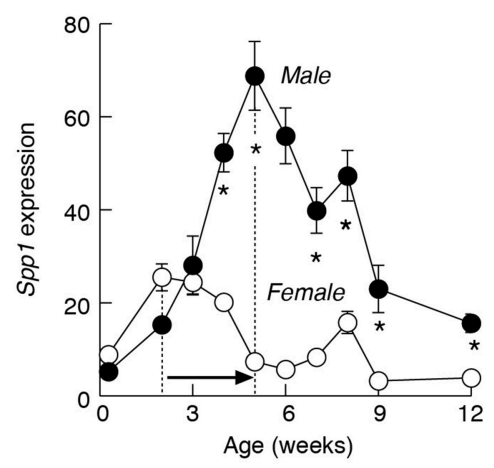

B

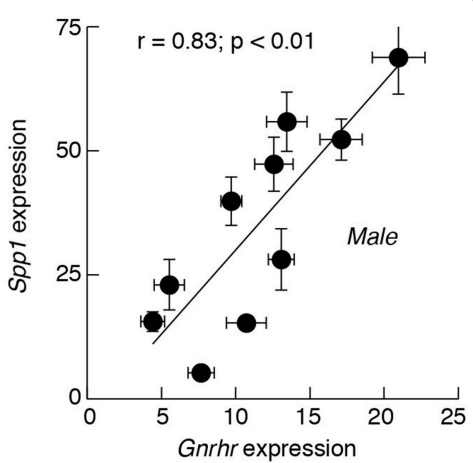

C

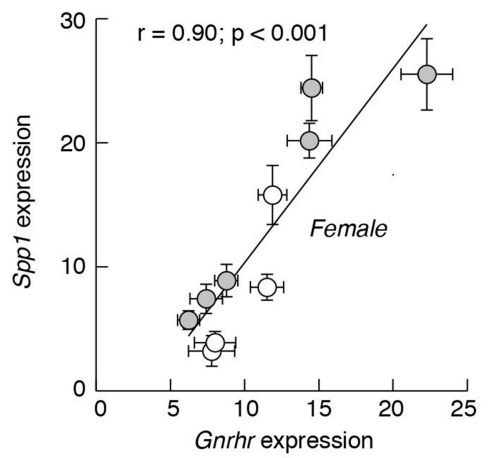

FIGURE 1 | The expression pattern of Spp1 mRNA in anterior pituitary of developing rats is comparable to Gnrhr expression. (A) The sex-specific developmental profiles of Spp1 expression. White circles: females; black circles: males. In postpubertal females, the mean values are derived from regularly cycling animals in proestrus, estrus, and diestrus 1 and 2 stages of the cycle. (B,C) The expression of Spp1 correlates with expression of Gnrhr, a gonadotroph marker gene, in male (B) and female (C) pituitaries. Data points shown are mean \pm SEM values from 6 to 37 animals per group, relative to Gapdh (set as 100\%). Correlation and linear regression analyses and statistical evaluation are described in Material and Methods; $r$, coefficient of correlation. The mean \pm SEM values for Gnrhr are derived from (38). Asterisks indicate significant differences between pairs (A); the $p$ values for $r$ coefficient are shown on top of panels (B,C). Gray circles, prepubertal females; white circle, postpubertal females (C).

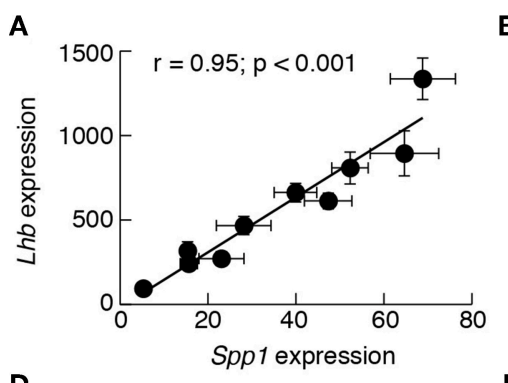

D

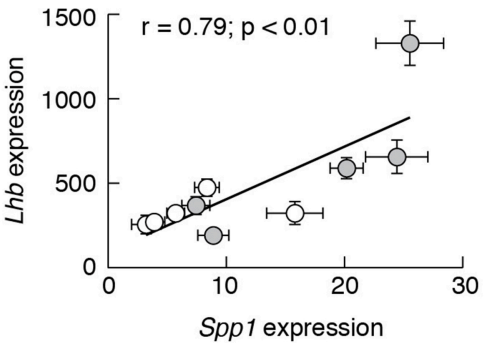

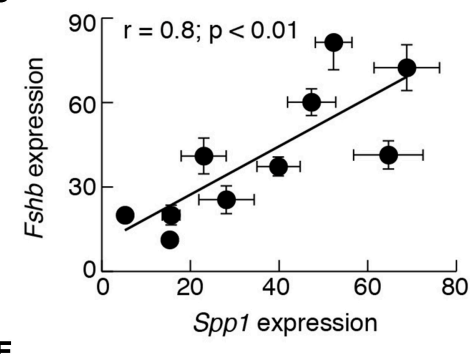

E

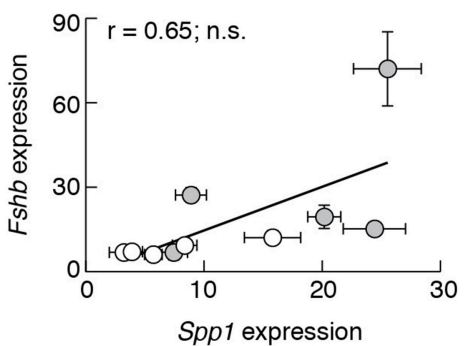

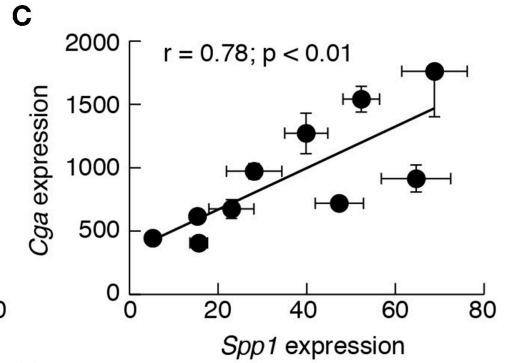

F

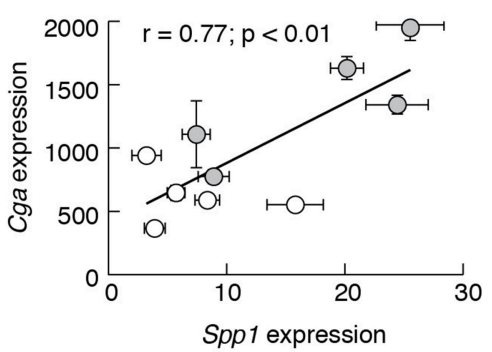

G
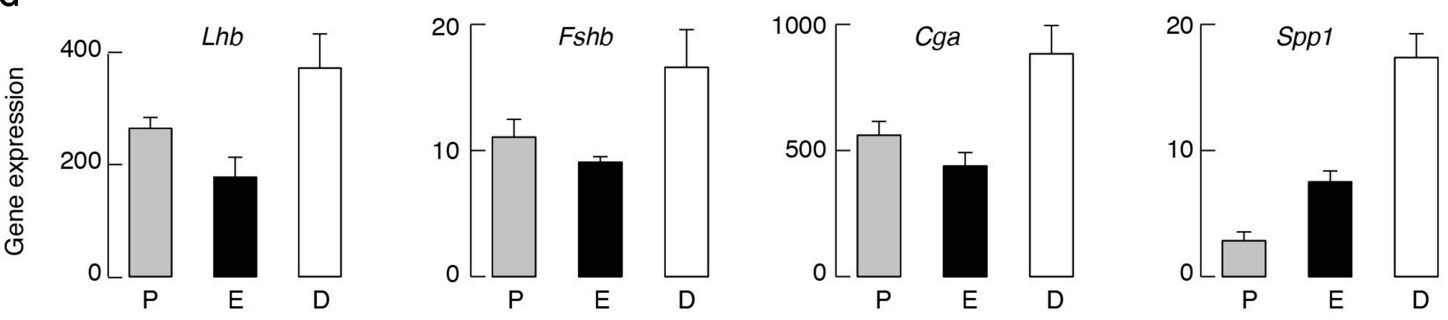

FIGURE 2 | The expression of Spp1 correlates with expression of other gonadotroph marker genes in a sex-specific manner in anterior pituitary tissue from developing rats. Correlation between Spp1 vs. Lhb (A,D), Fshb (B,E), and Cga (C,F) expression. Data points for Lhb, Fshb, and Cga are derived from (35). n.s., non-significant. Gray circles, prepubertal females; white circles, postpubertal females. (G) The expression of gonadotroph marker genes and Spp1 in postpubertal females during estrous cycle: P, proestrus; E, estrus; D, diestrus-1 (metestrus) + diestrus-2. 


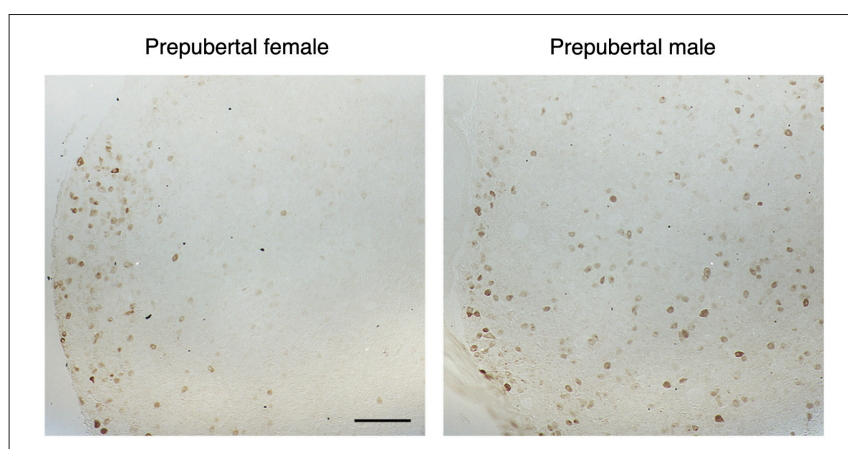

FIGURE 3 | The sex-specific expression pattern of osteopontin (OPN) in the anterior pituitary tissue from prepubertal female and male rats. Male tissue sections contained greater number of labeled cells which were more homogenously distributed, when compared to female pituitary tissue. Scale bar of $200 \mu \mathrm{m}$ applies to both images.

vs. proestrus) and the largest was during the diestrus (17.36 \pm 1.89, $n=15 ; P<0.01$ vs. proestrus).

In contrast to gonadotroph marker genes, no correlation was observed between Spp1 expression vs. expression of Pomc, a marker gene for corticotrophs and melanotrophs, Tshb, a marker gene for thyrotrophs, Gh1, a marker gene for somatotrophs, and $\mathrm{Prl}$, a marker gene for lactotrophs (data not shown).

These results suggest that $S p p 1$ is expressed in pituitary gland in a sex-specific manner and that expression of this gene during development is synchronized with expression of gonadotroph signature genes, a finding consistent with a hypothesis that this gene is active only in gonadotrophs. However, the expression of Spp1 is regulated differently than the expression of gonadotroph marker genes during the estrous cycle.

\section{In vivo OPN Is Specifically Expressed in Pituitary Gonadotrophs}

To clarify this hypothesis, we performed an immunohistochemical analysis of pituitary tissue using antibodies specific for OPN, a protein encoded by $S p p 1, \mathrm{LH} \beta$, and FSH $\beta$. This analysis confirmed that OPN was also present in both female and male pituitary cells during sexual maturation. Figure 3 shows OPN-positive cells in female and male pituitaries from prepubertal animals, with more positive cells observed in male pituitaries. In parallel to mRNA expression, OPNpositive cells were also visible in peripubertal and postpubertal anterior pituitaries from both sexes and with greater number of labeled cells in male tissue sections (data not shown). Finally, double immunohistochemical labeling indicated that all OPNpositive cells in males and females were also LH $\beta$ positive, i.e., that $S p p 1 / \mathrm{OPN}$ are specifically expressed in LH $\beta$-positive gonadotrophs (Figure 4). Finally, triple immunohistochemical labeling indicated that most of the OPN positive cells in males were positive for both $\mathrm{LH} \beta$ and $\mathrm{FSH} \beta$ (Figure 5).

However, OPN labeling was not visible in all gonadotrophs (Figures 4, 5), suggesting that in vivo expression of OPN was bellow detection by immunohistochemistry in a fraction of these cells. In parallel to Spp1 expression during estrous cycle
(Figure 2G), greater number of OPN-positive gonadotrophs could be observed in diestrus when compared to other stages of the estrous cycle. Furthermore, OPN-positive gonadotrophs were more intensely labeled in diestrus (Figure 6). Finally, the difference in the expression of gonadotroph marker genes and Spp1 during estrous cycle suggest that Spp1 expression was probably independent of the status of GnRH secretion.

\section{Basal Spp1 Expression Is Upregulated in Cultured Pituitary Cells}

Next, we investigated the expression of basal Spp1 in primary pituitary cell cultures. After cell dispersion, the Spp1 expression progressively increased as a function of time in both female and male pituitary cell cultures. The upregulation of Spp1 expression persisted over several days; Figure 7A illustrates the time course of upregulation of $S p p 1$ expression during the first 3 days of culturing in medium 199 containing 10\% horse serum. Similar growth profiles in Spp1 expression were observed in cells cultured in medium 199 containing fetal calf serum (data not shown). In cells cultured in serum-free and $0.1 \%$ BSAcontaining medium, the growth in gene expression was not abolished and the rate of expression was only slightly attenuated. For example, in cells from 7-week old females cultured overnight in horse-serum containing medium or $0.1 \%$ BSA-containing medium, the expression of Spp1 was $53.21 \pm 2.52$ and 43.88 \pm 3.26 , respectively. In contrast to $S p p 1$, the expression of Gnrhr decreased progressively with culturing time [Figure 7B and (38)]. This indicates that loss of pulsatile GnRH stimulation and tridimensional pituitary structure has opposite effect on expression of Spp1 and gonadotroph marker genes.

The Spp1 expression in pituitary cells cultured in poly-Dlysine coated wells for $48 \mathrm{~h}$ was $112 \pm 24$, while in collagencoated wells was $134 \pm 36$, both relative to Gapdh expression ( $n$ $=6$ ). However, the rate in Spp1 expression decreased in female pituitary cells cultured in horse serum- and BSA-containing medium when media were replaced with fresh medium once or twice during $72 \mathrm{~h}$ incubation (Figure $7 \mathrm{C}$ ). In contrast, the decay in Gnrhr expression was not affected by washing procedure (Figure 7D). These observations are consistent with a hypothesis that an autocrine or paracrine factor, other than GnRH (39), stimulates Spp1 expression.

\section{Spp1 mRNA Expression Is Not Regulated by $\mathrm{GnRH}$}

To evaluate effects of GnRH on Spp1 mRNA expression more directly, we performed two types of experiments, in vitro and in vivo. Figure 8 summarizes experiments done with pituitary cells derived from 4 -week old females and males. Treatment of $20 \mathrm{~h}$-old cultures of these cells with $10 \mathrm{nM} \mathrm{GnRH}$ during $8 \mathrm{~h}$ incubation did not affect $S p p 1$ expression (Figure 8A). In contrast, the expression of a sister gene Dmp1 increased in a time-dependent manner, with a peak in response after $4 \mathrm{~h}$ of incubation (Figure 8B). The expression of Gnrhr was also stimulated by GnRH in both pituitary cultures, from females and males (Figure 8C). 


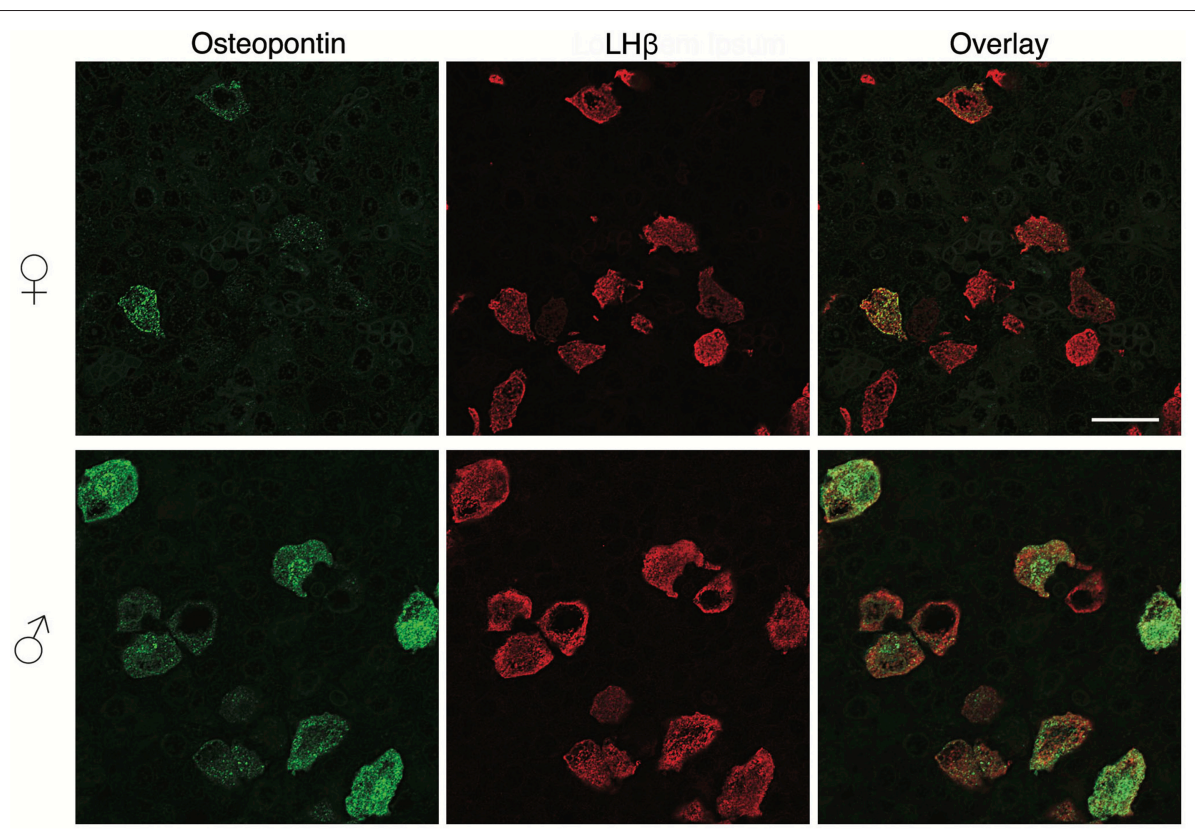

FIGURE 4 | OPN expression in the adult pituitary tissue is sex-specific and restricted to gonadotrophs. Immunofluorescence staining for OPN and LH $\beta$ in the anterior pituitary tissue from adult female (top) and male (bottom) rats. Scale bar of $20 \mu \mathrm{m}$ applies to all images.

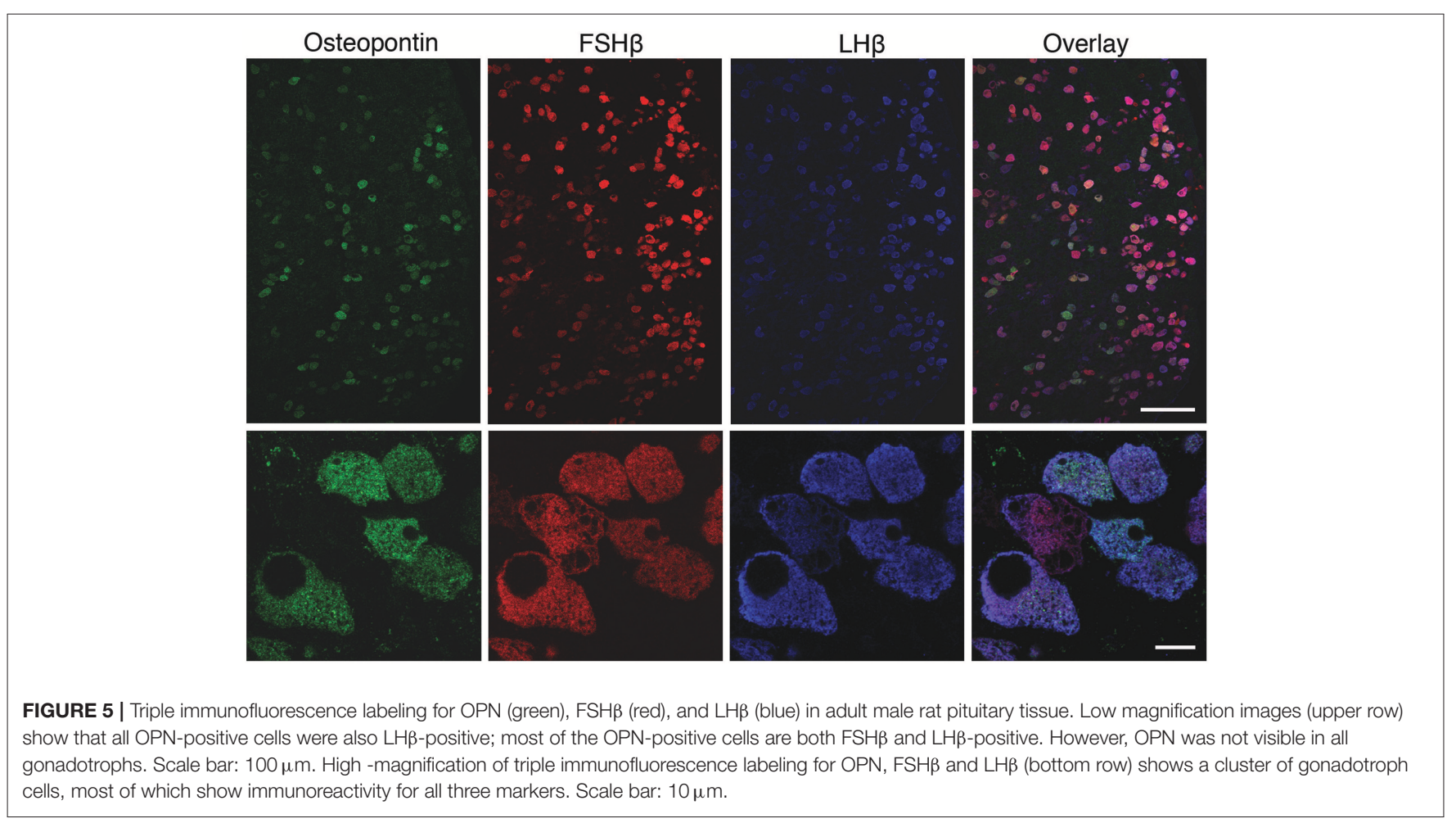

The results of in vivo experiments with 4-week-old female and male rats were summarized in Figure 9. Animals were intraperitoneally injected with saline solution (solvent) or $5 \mu \mathrm{g}$ of buserelin acetate, a GnRHR agonist. Animals were sacrificed 3,6 , and $9 \mathrm{~h}$ after injection, blood was collected for serum LH measurements and pituitary glands were removed for qRT-PCR analysis. LH measurements confirmed that stimulus secretion coupling was operative under these experimental conditions (data not shown). We also observed a progressive Dmp1 expression of comparable levels to those observed in cultured pituitary cells (Figure 9A). However, buserelin acetate treatment did not affect Spp1 expression (Figure 9B). 


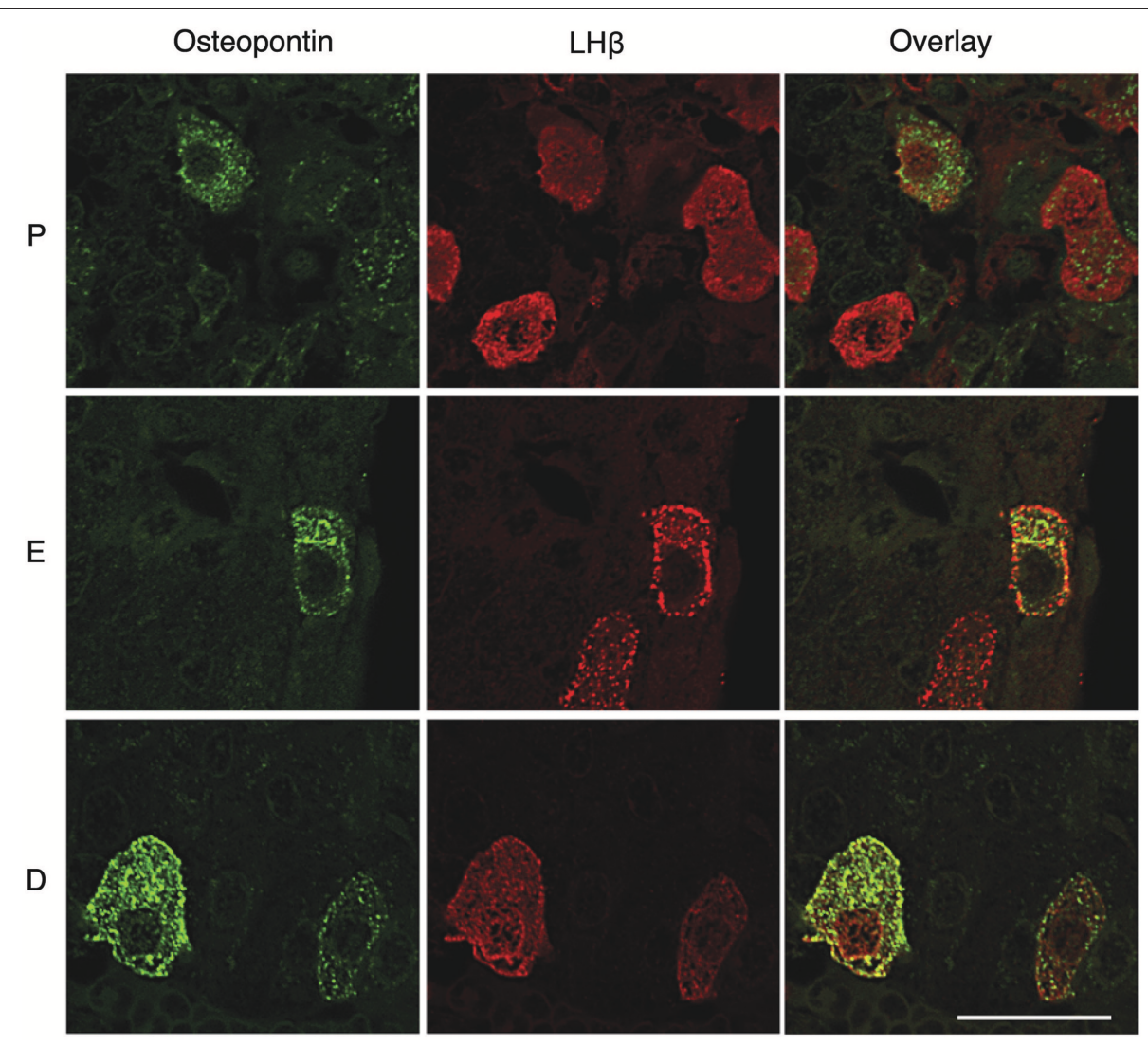

FIGURE 6 | Estrous cycle influences OPN expression in the pituitary tissue. Gonadotrophs were more intensively labeled in diestrus (D), when compared to proestrus (P) and estrus (E). Scale bar $=20 \mu \mathrm{m}$ applies to all images.

We also performed two in vitro experiments using pituitary cells from 7-week-old female rats. In the first experiment, cells were cultured overnight in GnRH-free medium, and after that for $2-60 \mathrm{~h}$ in the presence and absence of $10 \mathrm{nM} \mathrm{GnRH}$. Under these conditions, GnRH-induced expression of Dmp1 (Figure 10A, top), with kinetics comparable to that we reported earlier, with a peak in response observed after $6 \mathrm{~h} \mathrm{GnRH}$ application, followed by a decay to levels that were on the edge of detection by qRT-PCR (32). The subsequent application of GnRH was inefficient, indicating that decay in $D m p 1$ expression is not due to degradation of $\mathrm{GnRH}$ but reflects desensitization of response (data not shown). In contrast, during $60 \mathrm{~h}$ of incubation, there was a progressive increase in Spp1 expression in both controls and $10 \mathrm{nM}$ GnRH-treated cells, but no significant differences between treated and untreated cells at the same time points (Figure 10A, bottom).

In the second experiment, pituitary cells were initially cultured for $96 \mathrm{~h}$ without $\mathrm{GnRH}$, followed by washing and addition of fresh medium supplemented with $10 \mathrm{nM}$ GnRH. Under these conditions, we also observed a time-dependent induction of $D m p 1$ expression by GnRH (Figure 10B, top), indicating that $\mathrm{GnRH}$-induced intracellular signaling and stimulus transcriptional coupling were still operative. However, the expression of $S p p 1$ was comparable in all groups (Figure 10B, bottom). In vivo injected buserelin acetate to 7 -week old females also stimulated Dmp1 expression and did not affect Spp1 expression (Figure 10C).

In vitro experiments were also done with pituitary cultures from 2-, 3-, 6-, 8-, 9-, and 12-week old animals and no change in Spp1 expression was observed in GnRH (10 nM)-treated cells (data not shown), further supporting the view that GnRH does not regulate Spp1 expression. We also treated cultured cells with $100 \mathrm{nM}$ thyrotropin-releasing hormone, $100 \mathrm{nM}$ corticotropinreleasing hormone, $100 \mathrm{nM}$ somatostatin-28, $1 \mu \mathrm{M}$ dopamine, $1 \mu \mathrm{M}$ oxytocin, $1 \mu \mathrm{M}$ PACAP28, $1 \mu \mathrm{M}$ endothelin- $1,25 \mathrm{ng} / \mathrm{ml}$ activin, $100 \mathrm{ng} / \mathrm{ml} \mathrm{IGF,} 10 \mathrm{ng} / \mathrm{ml} \mathrm{EGF}$, and $2 \mathrm{ng} / / \mathrm{ml}$ TGF $\beta 1$ for $6 \mathrm{~h}$. None of these treatments affected Spp1 expression in vitro (data not shown).

\section{DISCUSSION}

The expression of OPN mRNA in pituitary gonadotrophs has been reported previously (33). Here we provide further evidence that $S p p 1$ is expressed in gonadotrophs but not in other pituitary cell types. First, the developmental pattern of Spp1/OPN is sexspecific and comparable to that observed for Lhb, Fshb, and Gnrhr (35), the well-established marker genes for gonadotrophs (40). Second, there was no correlation between Spp1 vs. Gh1, Prl, $T s h b$, and Pomc, the marker genes for somatotrophs, lactotrophs, 

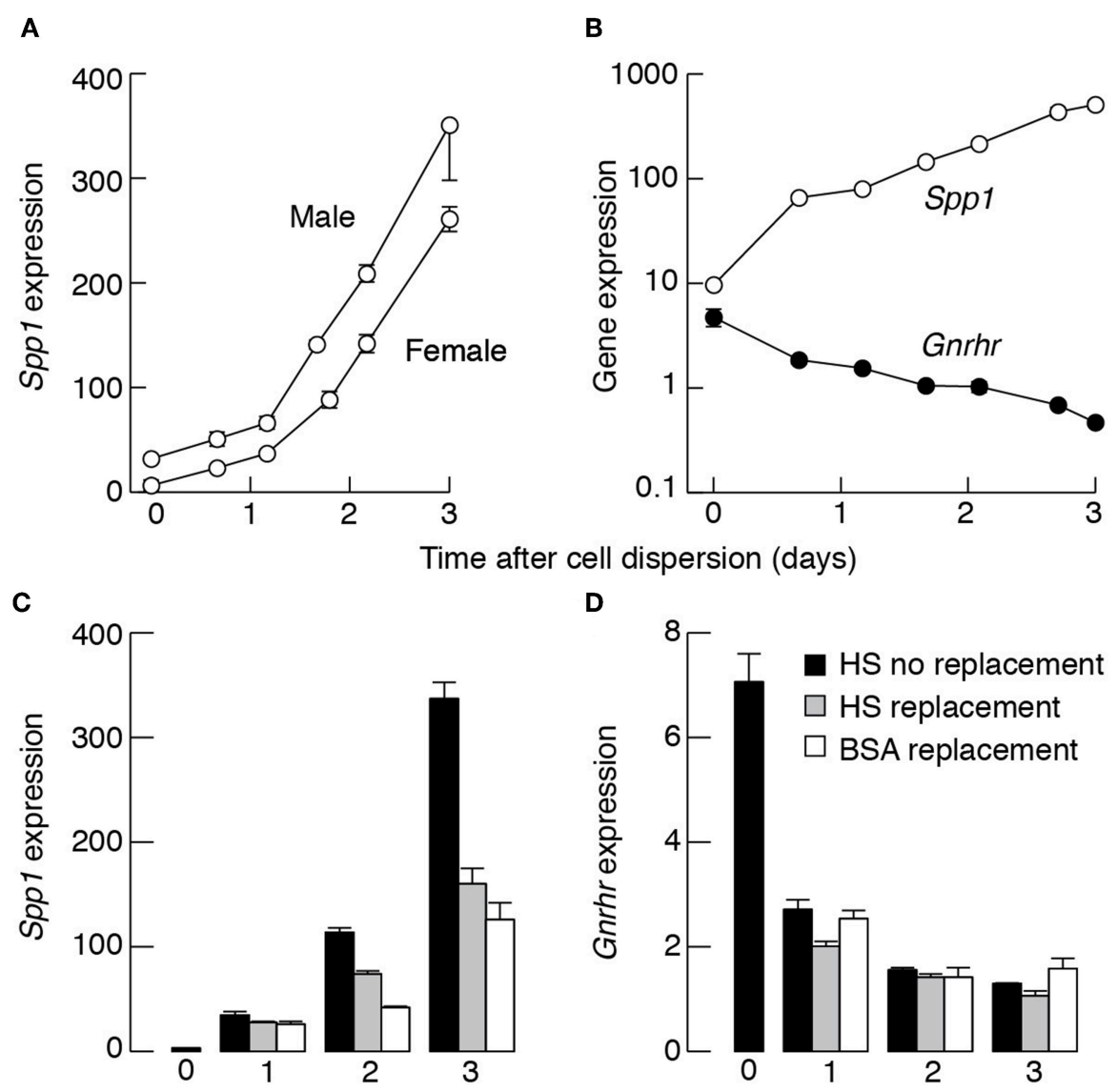

Time after cell dispersion (days)

FIGURE 7 | Culturing of dispersed pituitary cells stimulates Spp1 expression. (A) The time course of basal Spp1 expression in cultured pituitary cells. Cells were derived from 7-week-old female and male rats. Zero indicates Spp1 expression levels immediately after cell dispersion. Cells were cultured in medium 199 containing horse serum. (B) Opposite effects of dispersion and culturing of pituitary cells from females on Spp1 and Gnrhr expression. In (A) and (B), cells were continuously cultured in medium 199 containing horse serum without replacement of old medium with fresh. (C,D) Effects of replacement of culturing medium on rate of basal Spp1 (C) and Gnrhr (D) expression. Old media were replaced with fresh media after 12, 36, and $60 \mathrm{~h}$ incubation and cells were collected for mRNA extraction immediately after dispersion, and 24,48 , and $72 \mathrm{~h}$ after dispersion.

A

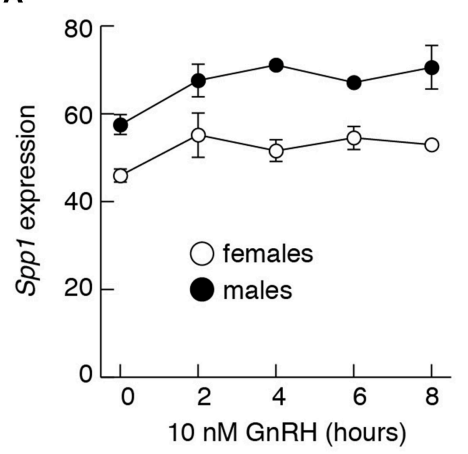

B

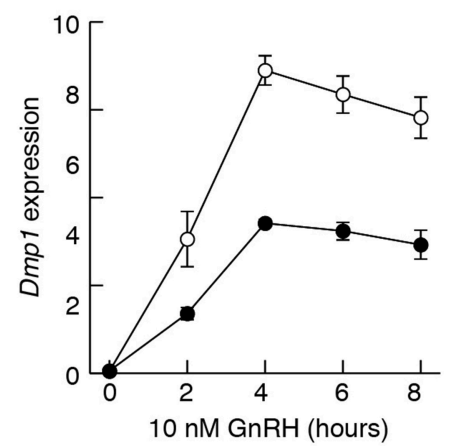

C

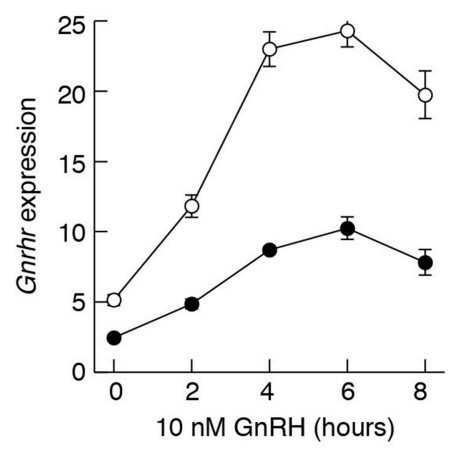

FIGURE 8 | The lack of an ability of GnRH to stimulate Spp1 expression in cultured anterior pituitary cells. Experiments were performed with cells from 4-week-old females and males. Cells were cultured overnight in medium 199 containing horse serum, which was replaced with BSA-containing medium 199 supplemented with $10 \mathrm{nM} \mathrm{GnRH}$ in the morning, cultured for 0 to $8 \mathrm{~h}$, and mRNA was extracted for measurement of Spp1 (A), Dmp1 (B), and Gnrhr (C) expression. 


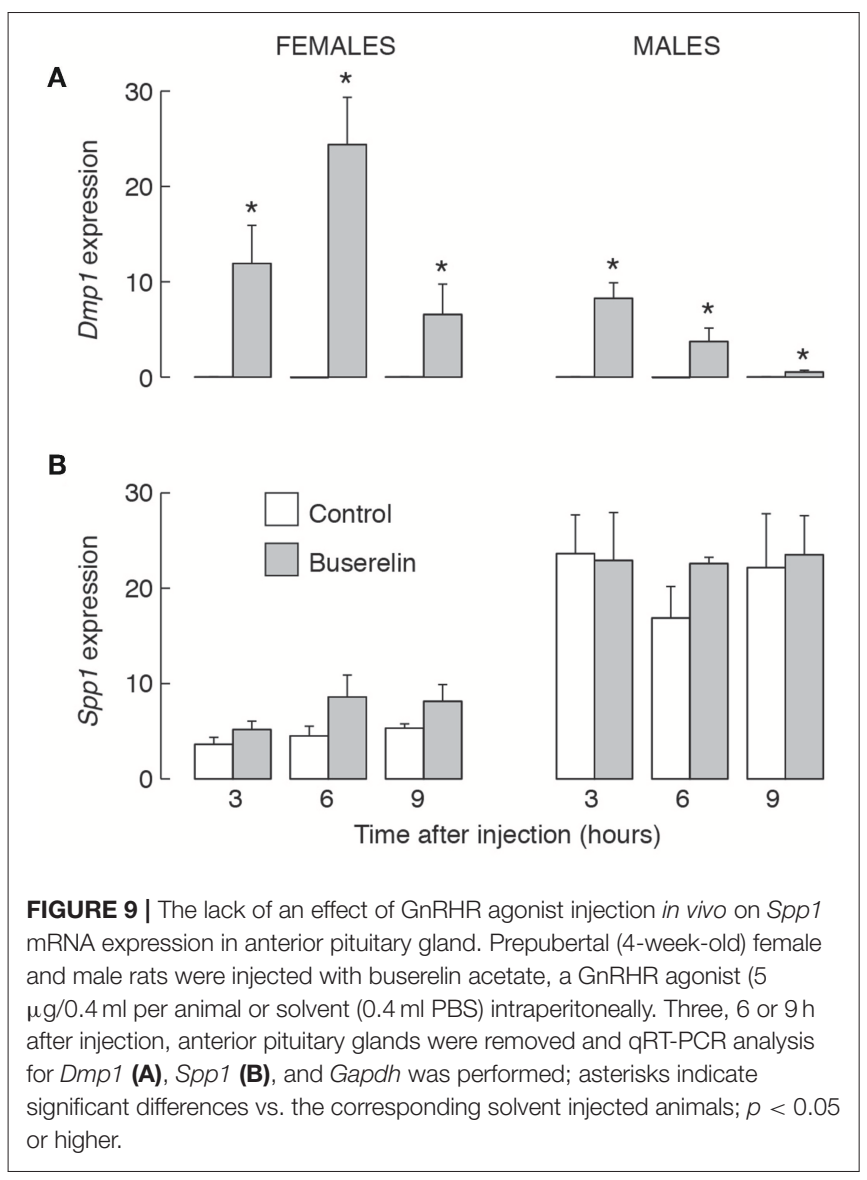

thyrotrophs, and corticotrophs, respectively. Third, immunohistochemical analysis showed the expression of OPN only in LH $\beta$ - and LH $\beta / F S H \beta$ - positive cells. Our recent single cell RNAsequence also showed the expression of Spp1 in gonadotrophs only (NCBI Sequence Read Archive accession SRP151788). Thus, Spp1 is an additional gonadotroph-specific gene.

The expression of gonadotroph-marker genes, such as Lhb, $F s h b$, and Gnrhr, is regulated by GnRH (41). Previously we also showed that pulsatile GnRH application facilitated expression of numerous genes, including Fshb, Cga, and Gnrhr, but not Spp1 (32). Here we show that both in vitro and in vivo activations of GnRHR were ineffective in induction of Spp1. We also show that Spp1 expression varies during estrous cycle, with the pattern not comparable to endogenous GnRH release. Activation of other G protein-coupled receptors expressed in gonadotrophs was also ineffective. In other tissues, the expression of OPN is up-regulated by numerous growth and differentiation factors, including transforming growth factor- $\beta$ superfamily, bone morphogenic proteins, epidermal growth factors, platelet-derived growth factor, and inflammatory cytokines. Also, steroids, retinoic acid, glucocorticosteroids, and 1.25-dihydroxyvitamin D3 increase OPN expression (42). In our experiments, IGF, EGF, TGF $\beta 1$, and activin were ineffective.

We established previously that Dmp1 is a gonadotrophspecific gene within cells of anterior pituitary gland (32). However, the expression of these two SIBLING genes in gonadotrophs varies. Both genes are expressed in vivo in a sexspecific manner, but the expression of $S p p 1$ was always higher in males and Dmp1 was always better expressed in females. In postpubertal females, the expression of $S p p 1$ was largest during the diestrus stage of estrous cycle, whereas the expression of Dmp1 was most prominent during the late proestrus. In further contrast to Spp1, the expression of Dmp1 in vivo and in vitro was regulated by GnRHR; continuous GnRH application caused a transient stimulation of $D m p 1$ expression followed by prolonged desensitization. Thus, although $D m p 1$ is a sister gene of $S p p 1$, it follows the expression pattern of Lhb, Fshb, and Gnrhr $(32,41)$.

The role of pituitary gonadotrophs in reproduction is wellestablished. Work with expression of SIBLINGs in pituitary gland indicates that gonadotrophs may have an additional cell-type specific function in anterior pituitary gland. At the present time, this function is unknown. Based on functions of OPN and DMP1 in other tissues, we may speculate that these proteins contribute to the proper organization of the cell-ECM tridimensional network, the former in GnRHR-dependent manner and the latter in a GnRHR-independent manner. The work on development of pituitary gland has indicated that, at birth, the pituitary cell types are roughly organized into layers with gonadotrophs being the most ventral (43). However, by adulthood spatial organization of the cell types appears more random (44). It has also been proposed that layering of pituitary cell types at birth could be required to establish networks of specific cell types, rather than a relationship with the timing of cell cycle exit (45). Thus, it is reasonable to speculate the potential role of these proteins in postnatal organization of pituitary.

We also present evidence, for the first time, that Spp1 expression increased progressively after pituitary cell dispersion in both female and male cultures, reaching 30-40-fold increase in mRNA levels within 3 days. Such response suggests that OPN signals to other pituitary cell types for changes in cellmatrix network structure. Spp1 is also upregulated as early as $6 \mathrm{~h}$ after skin wounding and healing was altered in mice lacking a functional Spp1. This and some additional analyses led the authors to conclude that OPN has a role in tissue remodeling and during matrix reorganization after injury (46). In general, OPN has been shown to promote attachment and spreading of a variety of cell types through its glycine-arginine-glycine-aspartate-serine cell binding domain, i.e., OPN can be classified as an adhesive protein (47). Thus, OPN may represent an initial signal for reconstruction of tridimensional structure of pituitary gland.

Consistent with this hypothesis, it has been shown that rat anterior pituitary cells in vitro can partly reconstruct the topographic nature of the pituitary gland, which includes few junctional complexes between hormone-producing cells (48). More recently, the same group reported about reassembly of anterior pituitary organization by hanging drop cell culture. Specifically, the authors reported that the topographic affinities of hormone-producing cells were maintained, that folliculostellate cells were interconnected with typical cytoplasmic protrusions to form tridimensional network, with the major ECM components, collagens and laminin, being deposited and distributed around the cells (49). It has also been reported that gonadotrophs can signal to the lactotrophs through the release of a paracrine 

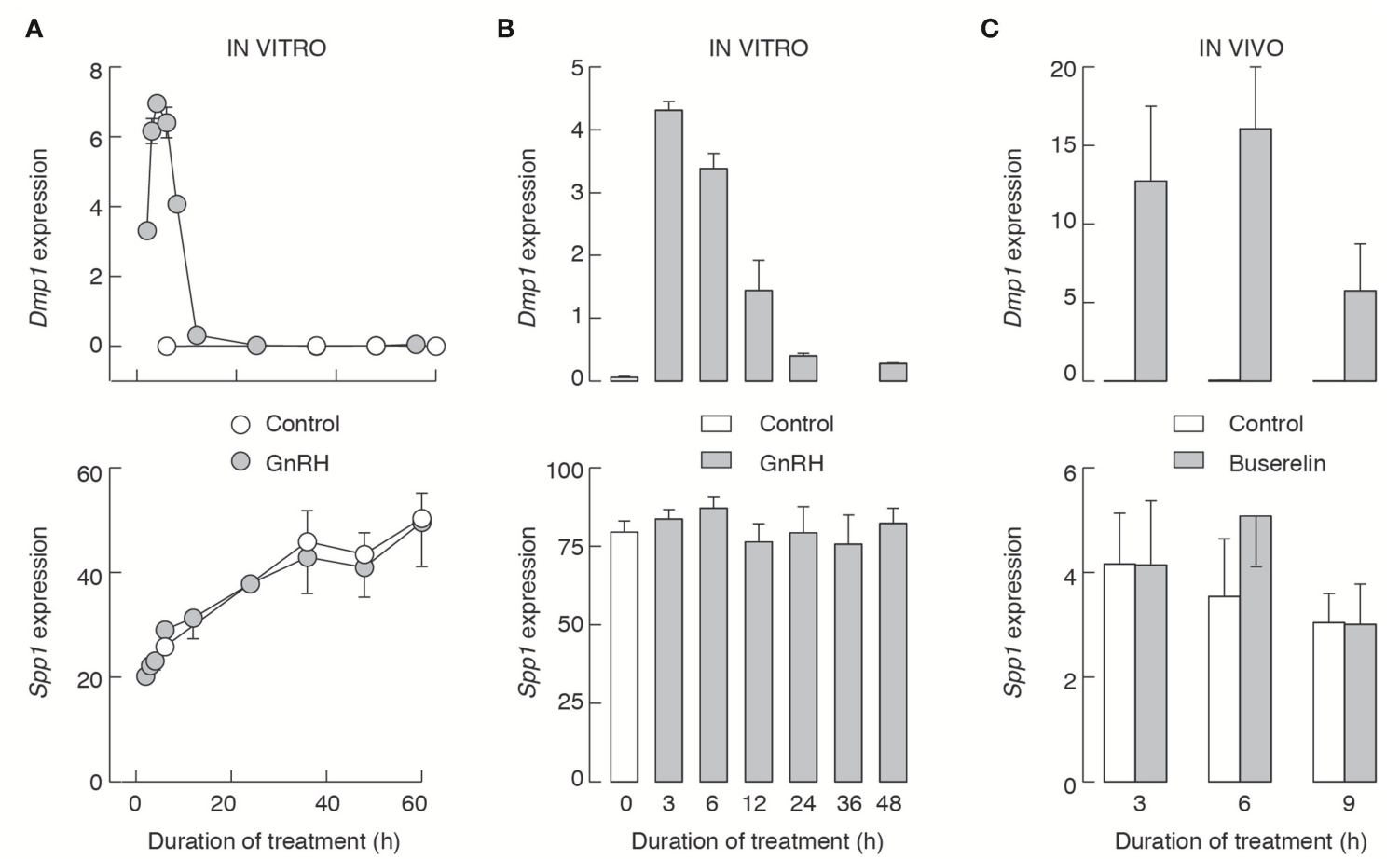

FIGURE 10 | The lack of an effect of GnRHR activation on Spp1 expression in vitro $\mathbf{( A , B )}$ and in vivo $\mathbf{( C )}$. Experiments were performed with 7 -week-old females. (A) Pituitary cells were cultured overnight in medium 199 containing horse serum, washed in the morning, and cultured in medium 199 supplemented with BSA with or without $10 \mathrm{nM}$ GnRH for 0-60 h prior to the end of experiments, and samples were analyzed for Dmp1 (top) and Spp1 (bottom) mRNA expression. (B) $96 \mathrm{~h}$ old cell cultures were treated as described in (A), up to $48 \mathrm{~h}$, and samples were analyzed for Dmp1 (top) and Spp1 (bottom) mRNA expression. (C) Animals were injected with buserelin acetate or solvent as described above. Gray bars and circles, GnRH/buserelin acetate-treated cells/animals; white bars and circles, solvent-treated cells/animals.

humoral factor distinct from $\mathrm{LH}$ and FSH and in a GnRHindependent manner (50). Further studies indicated that a common alpha subunit of pituitary gonadotropins accounts for influence of gonadotrophs on lactotroph functions (51-53). We may speculate that OPN is another protein released by gonadotrophs, which contributes to the crosstalk among anterior pituitary cells.

Dispersion of pituitary cells could be considered as the stress situation for pituitary tissue. In general, OPN plays a role in immune regulation and stress responses (54). It has also a role in mediating oxidative stress (55), mechanical stress (56), and cellular stress (57). OPN also plays a significant role in the regulation of the hypothalamus-pituitary-adrenal axis hormones in animals exposed to chronic restraint stress (58). Cancer also reflects the loss of tissue organization and aberrant behavior of the cellular components and tumors have been likened to wounds that fail to heal (4). Not surprising, elevated OPN expression has been detected in numerous tumors (59-61). Elevated OPN levels were also detected in silent corticotroph adenomas and non-functioning gonadotroph adenomas (62). OPN expression is inhibitable on the levels of gene transcription and the RNA message, and its protein ligand activity can be blocked with antibodies or synthetic peptides, which led to idea to consider OPN as a candidate target for cancer therapy (63).

For understanding the signaling function of OPN in intact pituitary gland, dispersed pituitary cells, and pituitary tumors, it is critical to identify OPN receptors and cell types expressing these receptors. In general, OPN binds to several integrins, including $\alpha \mathrm{v}(\beta 1, \beta 3$, or $\beta 5)$, and $(\alpha 4, \alpha 5, \alpha 8$, or $\alpha 9) \beta 1$, and is a ligand for CD44 receptor splice variants, specifically v6 and/or v7 possibly in conjunction with a $\beta 1$ integrin (63). It is also known that exogenous addition of OPN to OPN-/- osteoclasts increased the surface expression of CD44 (64). The expression of $\alpha \mathrm{v} \beta 3$ integrin was reported in immortalized $\mathrm{GH}_{3}$ lacto-somatotrophs (65). It has also been reported that cultured rat anterior pituitary cells expressed the $\beta 1$ integrin subunit (11) as well as that integrin $\beta 1$ signaling is required for the proliferation of folliculostellate cells in rat anterior pituitary gland under the influence of ECM (66). To our best knowledge, at the present time no data exist describing the expression of $C d 44$ and its protein in normal mammalian anterior pituitary cells.

In summary, here we provide further evidence for the expression of Spp1 and Dmp1 in pituitary gonadotrophs, but not other pituitary cell types, in an age-, sex-, and estrous cycle stage-specific manner. Two genes also differ in regulation of their expression; Dmpl expression is regulated by $\mathrm{GnRH}$, whereas Spp1 expression increases progressively in culturing pituitary cells in a $\mathrm{GnRH}$-independent manner, presumably in response to an unidentified paracrine factor. Further work should be focused on secretion of these two proteins by gonadotrophs under different experimental paradigms, characterization of integrin and CD44 receptors within the secretory and non-secretory anterior pituitary cells and their signaling pathways, and function in pituitary gland. 


\section{ETHICS STATEMENT}

All experiments were approved by the NICHD Animal Care and Use Committee.

\section{AUTHOR CONTRIBUTIONS}

SS and IB: conceptualization. IB, MJ, RP, DA, and MK: experimental work. SS: writing-original draft. SS, IB, MJ, and RP: writing-review and editing. SS and IB:

\section{REFERENCES}

1. Lukashev ME, Werb Z. ECM signalling: orchestrating cell behaviour and misbehaviour. Trends Cell Biol. (1998) 8:437-41. doi: 10.1016/S0962-8924(98)01362-2

2. Paez-Pereda M, Kuchenbauer F, Arzt E, Stalla GK. Regulation of pituitary hormones and cell proliferation by components of the extracellular matrix. Braz J Med Biol Res. (2005) 38:1487-94. doi: 10.1590/S0100-879X2005001000005

3. Theocharis AD, Skandalis SS, Gialeli C, Karamanos NK. Extracellular matrix structure. Adv Drug Deliv Rev. (2016) 97:4-27. doi: 10.1016/j.addr.2015.11.001

4. Frantz C, Stewart KM, Weaver VM. The extracellular matrix at a glance. J Cell Sci. (2010) 123:4195-200. doi: 10.1242/jcs.023820

5. Hynes RO. Integrins: bidirectional, allosteric signaling machines. Cell. (2002) 110:673-87. doi: 10.1016/S0092-8674(02)00971-6

6. Fujiwara K, Jindatip D, Kikuchi $\mathrm{M}$, Yashiro $\mathrm{T}$. In situ hybridization reveals that type I and III collagens are produced by pericytes in the anterior pituitary gland of rats. Cell Tissue Res. (2010) 342:491-5. doi: 10.1007/s00441-010-1078-1

7. Horiguchi K, Kouki T, Fujiwara K, Kikuchi M, Yashiro T. The extracellular matrix component laminin promotes gap junction formation in the rat anterior pituitary gland. J Endocrinol. (2011) 208:225-32.

8. Horiguchi K, Syaidah R, Fujiwara K, Tsukada T, Ramadhani D, Jindatip D, et al. Expression of small leucine-rich proteoglycans in rat anterior pituitary gland. Cell Tissue Res. (2013) 351:207-12. doi: 10.1007/s00441-012-1513-6

9. Ramadhani D, Tsukada T, Fujiwara K, Azuma M, Kikuchi M, Yashiro T. Changes in laminin chain expression in pre- and postnatal rat pituitary gland. Acta Histochem Cytochem. (2014) 47:231-7. doi: 10.1267/ahc.14031

10. Tsukada T, Fujiwara K, Horiguchi K, Azuma M, Ramadhani D, Tofrizal A, et al. Folliculostellate cells are required for laminin release from gonadotrophs in rat anterior pituitary. Acta Histochem Cytochem. (2014) 47:239-45. doi: $10.1267 /$ ahc. 14036

11. Horacek MJ, Kawaguchi T, Terracio L. Adult adenohypophysial cells express beta 1 integrins and prefer laminin during cell-substratum adhesion. In Vitro Cell Dev Biol Anim. (1994) 30A:35-40. doi: 10.1007/BF02631416

12. Horacek MJ, Thompson JC, Dada MO, Terracio L. The extracellular matrix components laminin, fibronectin, and collagen IV are present among the epithelial cells forming Rathke's pouch. Acta Anat. (1993) 147:69-74. doi: 10.1159/000147484

13. Gonzalez B, Solano-Agama Mdel C, Gonzalez Del Pliego M, MendozaGarrido ME. Differences in cell migration of cultured pituitary cells from infantile and adult rats: participation of the extracellular matrix and epidermal growth factor. Int J Dev Neurosci. (2004) 22:231-9. doi: 10.1016/j.ijdevneu.2004.02.003

14. Denduchis B, Rettori V, McCann SM. Role of laminin on prolactin and gonadotrophin release from anterior pituitaries of male rats. Life Sci. (1994) 55:1757-65. doi: 10.1016/0024-3205(94)00344-0

15. Diaz ES, Rettori V, Suescun MO, Lustig L, McCann SM, Denduchis B. Role of type IV collagen in prolactin release from anterior pituitaries of male rats. Endocrine. (2002) 18:185-9. doi: 10.1385/ENDO:18:2:185

16. Kuchenbauer F, Hopfner U, Stalla J, Arzt E, Stalla GK, Paez-Pereda M. Extracellular matrix components regulate ACTH production and data analysis and figure preparation, supervision, and funding acquisition.

\section{FUNDING}

This work was supported by the National Institute of Child Health and Human Development Intramural Program-Project ZIA HD 000195-24 (1) and Ministry of Education, Science, and Technological Development of the Republic of Serbia, Grant III $41014(2)$.

proliferation in corticotroph tumor cells. Mol Cell Endocrinol. (2001) 175:1418. doi: 10.1016/S0303-7207(01)00390-2

17. Fisher LW, Fedarko NS. Six genes expressed in bones and teeth encode the current members of the SIBLING family of proteins. Connect Tissue Res. (2003) 44(Suppl. 1):33-40. doi: 10.1080/03008200390152061

18. Bellahcene A, Castronovo V, Ogbureke KU, Fisher LW, Fedarko NS. Small integrin-binding ligand $\mathrm{N}$-linked glycoproteins (SIBLINGs): multifunctional proteins in cancer. Nat Rev Cancer. (2008) 8:212-26. doi: 10.1038/nrc2345

19. Qin C, Baba O, Butler WT. Post-translational modifications of sibling proteins and their roles in osteogenesis and dentinogenesis. Crit Rev Oral Biol Med. (2004) 15:126-36. doi: 10.1177/154411130401500302

20. Kazanecki CC, Uzwiak DJ, Denhardt DT. Control of osteopontin signaling and function by post-translational phosphorylation and protein folding. J Cell Biochem. (2007) 102:912-24. doi: 10.1002/jcb.21558

21. Staines KA, MacRae VE, Farquharson C. The importance of the SIBLING family of proteins on skeletal mineralisation and bone remodelling. $J$ Endocrinol. (2012) 214:241-55. doi: 10.1530/JOE-12-0143

22. Ogbureke KU, Fisher LW. Expression of SIBLINGs and their partner MMPs in salivary glands. J Dent Res. (2004) 83:664-70. doi: $10.1177 / 154405910408300902$

23. Ogbureke KU, Fisher LW. Renal expression of SIBLING proteins and their partner matrix metalloproteinases (MMPs). Kidney Int. (2005) 68:155-66. doi: 10.1111/j.1523-1755.2005.00389.x

24. Yu H, Liu X, Zhong Y. The effect of osteopontin on microglia. Biomed Res Int. (2017) 2017:1879437. doi: 10.1155/2017/1879437

25. Wung JK, Perry G, Kowalski A, Harris PL, Bishop GM, Trivedi MA, et al. Increased expression of the remodeling- and tumorigenic-associated factor osteopontin in pyramidal neurons of the Alzheimer's disease brain. Curr Alzheimer Res. (2007) 4:67-72. doi: 10.2174/156720507779939869

26. Iczkiewicz J, Rose S, Jenner P. Osteopontin (Eta-1) is present in the rat basal ganglia. Brain Res Mol Brain Res. (2004) 132:64-72. doi: 10.1016/j.molbrainres.2004.09.013

27. Chabas D, Baranzini SE, Mitchell D, Bernard CC, Rittling SR, Denhardt DT, et al. The influence of the proinflammatory cytokine, osteopontin, on autoimmune demyelinating disease. Science. (2001) 294:1731-5. doi: 10.1126/science. 1062960

28. Comabella M, Pericot I, Goertsches R, Nos C, Castillo M, Blas Navarro J, et al. Plasma osteopontin levels in multiple sclerosis. J Neuroimmunol. (2005) 158:231-9. doi: 10.1016/j.jneuroim.2004.09.004

29. Terasawa M, Shimokawa R, Terashima T, Ohya K, Takagi Y, Shimokawa H. Expression of dentin matrix protein 1 (DMP1) in nonmineralized tissues. $J$ Bone Miner Metab. (2004) 22:430-8. doi: 10.1007/s00774-004-0504-4

30. Fisher LW, Jain A, Tayback M, Fedarko NS. Small integrin binding ligand Nlinked glycoprotein gene family expression in different cancers. Clin Cancer Res. (2004) 10:8501-11. doi: 10.1158/1078-0432.CCR-04-1072

31. Wei R, J.Wong PC, Kwok HF. Osteopontin - a promising biomarker for cancer therapy. J Cancer. (2017) 8:2173-83. doi: 10.7150/jca.20480

32. Kucka M, Bjelobaba I, Clokie SJ, Klein DC, Stojilkovic SS. Female-specific induction of rat pituitary dentin matrix protein-1 by GnRH. Mol Endocrinol. (2013) 27:1840-55. doi: 10.1210/me.2013-1068

33. Ehrchen J, Heuer H, Sigmund R, Schafer MK, Bauer K. Expression and regulation of osteopontin and connective tissue growth factor 
transcripts in rat anterior pituitary. J Endocrinol. (2001) 169:87-96. doi: 10.1677 joe. 0.1690087

34. Bargi-Souza P, Kucka M, Bjelobaba I, Tomic M, Janjic MM, Nunes MT, et al. Loss of basal and TRH-stimulated Tshb expression in dispersed pituitary cells. Endocrinology. (2015) 156:242-54. doi: 10.1210/en.2014-1281

35. Bjelobaba I, Janjic MM, Kucka M, Stojilkovic SS. Cell type-specific sexual dimorphism in rat pituitary gene expression during maturation. Biol Reprod. (2015) 93:21. doi: 10.1095/biolreprod.115.129320

36. Li S, Bjelobaba I, Yan Z, Kucka M, Tomic M, Stojilkovic SS. Expression and roles of pannexins in ATP release in the pituitary gland. Endocrinology. (2011) 152:2342-52. doi: 10.1210/en.2010-1216

37. Zemkova H, Kucka M, Bjelobaba I, Tomic M, Stojilkovic SS. Multiple cholinergic signaling pathways in pituitary gonadotrophs. Endocrinology. (2013) 154:421-33. doi: 10.1210/en.2012-1554

38. Bjelobaba I, Janjic MM, Tavcar JS, Kucka M, Tomic M, Stojilkovic SS. The relationship between basal and regulated Gnrhr expression in rodent pituitary gonadotrophs. Mol Cell Endocrinol. (2016) 437:302-11. doi: 10.1016/j.mce.2016.08.040

39. Krsmanovic LZ, Martinez-Fuentes AJ, Arora KK, Mores N, Tomic M, Stojilkovic SS, et al. Local regulation of gonadotroph function by pituitary gonadotropin-releasing hormone. Endocrinology. (2000) 141:118795. doi: 10.1210/endo.141.3.7392

40. McArdle CA, Roberson MS. Gonadotropes and GonadotropinReleasing Hormone Signaling. Sasn Diego, CA: Elsevier (2015). doi: 10.1016/B978-0-12-397175-3.00010-7

41. Ferris HA, Shupnik MA. Mechanisms for pulsatile regulation of the gonadotropin subunit genes by GNRH1. Biol Reprod. (2006) 74:993-8. doi: 10.1095/biolreprod.105.049049

42. Sodek J, Ganss B, McKee MD. Osteopontin. Crit Rev Oral Biol Med. (2000) 11:279-303. doi: 10.1177/10454411000110030101

43. Davis SW, Mortensen AH, Camper SA. Birthdating studies reshape models for pituitary gland cell specification. Dev Biol. (2011) 352:215-27. doi: 10.1016/j.ydbio.2011.01.010

44. Stallings CE, Kapali J, Ellsworth BS. Mouse models of gonadotrope development. Prog Mol Biol Transl Sci. (2016) 143:1-48. doi: 10.1016/bs.pmbts.2016.08.001

45. Bonnefont X, Lacampagne A, Sanchez-Hormigo A, Fino E, Creff A, Mathieu $\mathrm{MN}$, et al. Revealing the large-scale network organization of growth hormone-secreting cells. Proc Natl Acad Sci USA. (2005) 102:16880-5. doi: 10.1073/pnas.0508202102

46. Liaw L, Birk DE, Ballas CB, Whitsitt JS, Davidson JM, Hogan BL. Altered wound healing in mice lacking a functional osteopontin gene (spp1). J Clin Invest. (1998) 101:1468-78. doi: 10.1172/JCI2131

47. Brown LF, Papadopoulos-Sergiou A, Berse B, Manseau EJ, Tognazzi K, Perruzzi CA, et al. Osteopontin expression and distribution in human carcinomas. Am J Pathol. (1994) 145:610-23.

48. Noda T, Kikuchi M, Kaidzu S, Yashiro T. Rat anterior pituitary cells in vitro can partly reconstruct in vivo topographic affinities. Anat Rec A Discov Mol Cell Evol Biol. (2003) 272:548-55. doi: 10.1002/ar.a.10065

49. Tsukada T, Kouki T, Fujiwara K, Ramadhani D, Horiguchi K, Kikuchi $\mathrm{M}$, et al. Reassembly of anterior pituitary organization by hanging drop three-dimensional cell culture. Acta Histochem Cytochem. (2013) 46:121-7. doi: $10.1267 /$ ahc. 13015

50. Denef C, Andries M. Evidence for paracrine interaction between gonadotrophs and lactotrophs in pituitary cell aggregates. Endocrinology. (1983) 112:813-22. doi: 10.1210/endo-112-3-813

51. Begeot M, Hemming FJ, Dubois PM, Combarnous Y, Dubois MP, Aubert ML. Induction of pituitary lactotrope differentiation by luteinizing hormone alpha subunit. Science. (1984) 226:566-8. doi: 10.1126/science.6208610

52. Chabot V, Magallon T, Taragnat C, Combarnous Y. Two free isoforms of ovine glycoprotein hormone alpha-subunitstrongly differ in their ability to stimulate prolactin release from foetal pituitaries. J Endocrinol. (2000) 164:287-97. doi: $10.1677 /$ joe. 0.1640287

53. Denef C. Paracrinicity: the story of 30 years of cellular pituitary crosstalk. $J$ Neuroendocrinol. (2008) 20:1-70. doi: 10.1111/j.1365-2826.2007.01616.x

54. Wang KX, Denhardt DT. Osteopontin: role in immune regulation and stress responses. Cytokine Growth Factor Rev. (2008) 19:333-45. doi: 10.1016/j.cytogfr.2008.08.001

55. Itoh Y, Yasui T, Okada A, Tozawa K, Hayashi Y, Kohri K. Examination of the anti-oxidative effect in renal tubular cells and apoptosis by oxidative stress. Urol Res. (2005) 33:261-6. doi: 10.1007/s00240-005-0465-7

56. Fujihara S, Yokozeki M, Oba Y, Higashibata Y, Nomura S, Moriyama K. Function and regulation of osteopontin in response to mechanical stress. $J$ Bone Miner Res. (2006) 21:956-64. doi: 10.1359/jbmr.060315

57. Wai PY, Kuo PC. The role of Osteopontin in tumor metastasis. J Surg Res. (2004) 121:228-41. doi: 10.1016/j.jss.2004.03.028

58. Wang KX, Shi YF, Ron Y, Kazanecki CC, Denhardt DT. Plasma osteopontin modulates chronic restraint stress-induced thymus atrophy by regulating stress hormones: inhibition by an anti-osteopontin monoclonal antibody. $J$ Immunol. (2009) 182:2485-91. doi: 10.4049/jimmunol.0803023

59. Castello LM, Raineri D, Salmi L, Clemente N, Vaschetto R, Quaglia $\mathrm{M}$, et al. Osteopontin at the crossroads of inflammation and tumor progression. Mediators Inflamm. (2017) 2017:4049098. doi: 10.1155/2017/40 49098

60. Shi L, Wang X. Role of osteopontin in lung cancer evolution and heterogeneity. Semin Cell Dev Biol. (2017) 64:40-7. doi: 10.1016/j.semcdb.2016.08.032

61. Briones-Orta MA, Avendano-Vazquez SE, Aparicio-Bautista DI, Coombes JD, Weber GF, Syn WK. Osteopontin splice variants and polymorphisms in cancer progression and prognosis. Biochim Biophys Acta Rev Cancer. (2017) 1868:93-108A. doi: 10.1016/j.bbcan.2017.02.005

62. Mete O, Hayhurst C, Alahmadi H, Monsalves E, Gucer H, Gentili F, et al. The role of mediators of cell invasiveness, motility, and migration in the pathogenesis of silent corticotroph adenomas. Endocr Pathol. (2013) 24:191-8. doi: 10.1007/s12022-013-9270-y

63. Weber GF. The metastasis gene osteopontin: a candidate target for cancer therapy. Biochim Biophys Acta. (2001) 1552:61-85.

64. Chellaiah MA, Kizer N, Biswas R, Alvarez U, Strauss-Schoenberger J, Rifas L, et al. Osteopontin deficiency produces osteoclast dysfunction due to reduced CD44 surface expression. Mol Biol Cell. (2003) 14:173-89. doi: 10.1091/mbc.e02-06-0354

65. Kong D, Liu Y, Zuo R, Li J. DnBP-induced thyroid disrupting activities in GH3 cells via integrin alphavbeta3 and ERK1/2 activation. Chemosphere. (2018) 212:1058-66. doi: 10.1016/j.chemosphere.2018. 09.007

66. Horiguchi K, Fujiwara K, Ilmiawati C, Kikuchi M, Tsukada T, Kouki $\mathrm{T}$, et al. Caveolin 3-mediated integrin betal signaling is required for the proliferation of folliculostellate cells in rat anterior pituitary gland under the influence of extracellular matrix. J Endocrinol. (2011) 210:29-36. doi: 10.1530/JOE-11-0103

Conflict of Interest Statement: The authors declare that the research was conducted in the absence of any commercial or financial relationships that could be construed as a potential conflict of interest.

Copyright @ 2019 Bjelobaba, Janjic, Prévide, Abebe, Kucka and Stojilkovic. This is an open-access article distributed under the terms of the Creative Commons Attribution License (CC BY). The use, distribution or reproduction in other forums is permitted, provided the original author(s) and the copyright owner(s) are credited and that the original publication in this journal is cited, in accordance with accepted academic practice. No use, distribution or reproduction is permitted which does not comply with these terms. 